\title{
PATTERNS OF CHANGES IN RELIABILITY OF MILITARY OPERATORS, RECEIVING THE SIMULATED CONTRADICTORY INFORMATION
}

\author{
Kalnysh V.', Shvets A. ${ }^{2}$
}

\author{
'Institute for Occupational Health of National Academy of Medical Sciences of Ukraine, Kyiv \\ 2Ukrainian Military Medical Academy, Kyiv
}

Introduction. An information overload can affect the reliability and work capacity of military operators, stimulate increasing their emotional negatively outlined strain. An objective availability of the psychoemotional overload in a modern person requires developing a new, more improved access to assessment of work reliability and new psychophysiological approaches to validation of modern technologies for psychophysiological assessment of reliability of an operator's performance in conditions of time deficiency.

Purpose of the study is to reveal regularities and analyze psychophysiological patterns in changes of reliability of military operators' performance in processing the contradictory information in conditions of time deficiency.

Materials and methods. Studies on reliability of the operator's performance in simulation of information flows with contradictory information were conducted in 2012-2013. A sample of the studied individuals covered 54 military man-operators, aged 22-25, being in the state of acute emotional strain, caused by a procedure on entering a higher military institution. A scale of subjective assessments of mental states (CMSA - current mental state assessment) has been used for studying the emotional status. A specially designed computer program has been developed for simulating the operator's performance in the information processing in conditions of time deficiency and which, with the given probability, is accompanied by constellations of certain events, contradicting with the given algorithm of the operator's performance.

Results. An information overload in simulation of contradictory constellations significantly affects the emotional background of the studied persons by the majority of indicators. Two groups of operators have been distinguished with different levels of emotional strain and significantly different indices of reliability in operator's performance. The probability of an erroneous reaction after a fictitious signal on an erroneous action in persons with high emotional strain was higher, by 11,8 times, on the average, $\mathrm{p}<0,001$. Regulations for task performance for classification of operators on groups with high and low levels of reliability in processing the contradictory information have been developed.

Conclusion. It is established that according to the state of high emotional strain military operators are differed both by the background indices of the emotional strain and by its characteristics after an information overload, accompanied by the maintenance of the imbalance in subjective assessments of mental states and after information strain. A hypothesis was formulated on the presence of nonlinear effects, similar to Broca-Sulzer phenomenon, in processing information messages, which affect significantly the reliability of the operator's performance. A method of psychophysiological assessment of reliability of the operator's performance in military servicemen has been developed, based on simulation of presentation of contradictory constellations (a clash effect by I. P. Pavlov), which can additionally formulate certain negative emotional states in processing intensive information flows. A significant difference has been revealed in reactions on a fictitious error in individuals with different emotional strain, which is characterized by a significantly high part (by 11,8 times higher, $\mathrm{p}<0,001$ ) of the probability of occurrence a fictitious reaction after a fictitious signal on a erroneous action in individuals with high emotional strain. A model has been developed for supporting a physician's decision in assessing the reliability of the operator's performance by psychophysiological indices and criteria of referring a studied operator to groups with higher or low level of reliability in processing the contradictory information.

Key words: reliability of performance, emotional state, simulated contradictory information, Broca-Sulzer phenomenon

\section{Introduction}

In modern conditions the technological progress is developing so quickly and is so complicated that can result in information overload in individuals, being a real problem for citizens of Ukraine, including military operators. Specialists in the field of the mass media understand, that in the country, which has not taken any part in war operations, a person is unable to accept the intensive information flows, related to combat operations, military strategies and war tactics. The scientists in informatics and cybernetics have established the following growth of the information load in people: by the year 1800 the volume of information doubles every 50 years, since 1950 - 
every ten years, since 1970 - every five years, since 1990 - every year, and now it is going on much more quickly [16]. On this in view, American futurist Alvin Toffler said: «When a person is getting into an unregulated and rapidly changing situation or in a new saturated context, the accuracy of his/her actions falls. An individual is not able to give a proper estimation, on which the behavior depends» [10].

The information overload can affect the reliability and work capacity of military operators, stimulate increasing their emotional negatively colored strain. Therefore, studying mechanisms of supporting the high reliability in occupational activity of military operators in conditions of the unpredictable and rapidly changing environment is urgently necessary because a serviceman profession requires from a specialist to be self-disciplined and maximum active, due to intensive and constantly changing information flows.

The literature data indicate the importance of emotional processes as a type of mental reflection of the information overload, manifesting both in subjective experience and physiological and behavioral reactions [11]. These processes are associated with signal, motivating and energetic qualities as well as with functions of attention, memory and other psychodynamic qualities - they are closely bound and mutually supplement each other $[4-6,9,14]$. The objective presence of high psychoemotional overload in a modern man requires developing a new, more advanced view on the assessment of the reliability of an operator's work and developing new psychophysiological approaches to grounding modern technologies for the psychophysiological assessment of the reliability of the operator's work in conditions of information and time deficiency.

The purpose of the study is to identify regularities and analyze psychophysiological peculiarities in changing the reliability of servicemen's performance on processing the contradictory information in conditions of time deficiency.

\section{Materials and methods}

Studying the reliability of an operator's work in simulating a flow of tasks with the contradictory information was conducted in 2012-2013. The sample of the studied persons covered 54 male military operators, aged $22-25$, who were in the state of acute emotional strain, due to the procedure of entering a higher military institution. In order to study the emotional status a scale SOPAS- 8 was used for subjective assessments of mental states, developed in the laboratory for studying mental states in the Research Institute of Psychiatry (Czechoslovakia), adapted to a combined study of mental stability of an individual to factors of extreme performance [8]. Eight factors of mental state have been distinguished by this method: mental calmness and well-being $(P)$, feeling of power and energy $(E)$, desire for action, desire for performance $(\mathrm{A})$, impulsive reactivity $(\mathrm{O})$, feeling of mental anxiety or indignation and tension $(\mathrm{N})$, feeling of anxious expectation, fear, anxiety and alarm (V), mental depression and feeling of exhaustion (D), depressed mood, shock (S). The emotional status was studied immediately before and after a computerized psychophysiological testing on the reliability of the operator's performance. It was used a specially designed computed program, allowing to simulate an operator's performance on the information processing in conditions of time deficiency, which, under a certain probability, was accompanied by the constellation of some contradictory events, being in contradiction with the given algorithm of the operator's actions «Simulation of negative emotions» [3]. In the study there have been used the following options:

- signal exposure - time during which the screen displays tasks and expected responses on the test $1000 \mathrm{~ms}$;

- time for a pause - time after the exposure, within which the task is not displayed on the screen, but a response to the test by a subject is expected 100 ms;

- time for a «dead zone» - time after a pause, during which a task does not appear on the screen and a delay for a subject is set off, regardless the correctness of the response $-100 \mathrm{~ms}$;

- per cent of fictitious errors (a stimulator of controversial events) $-10 \%$ of the number of tasks.

In order to determine the reliability of the test the following method was used. The testing took 30 minutes. However, in order to analyze the reliability of the test and to state a significant manifestation of the fatigue there have been distinguished two test sections: I - execution of the first 200 tasks; II - execution of the last 200 tasks.

The analysis of the results was made, using biometrics techniques, cluster and discriminant analyses and the software package STATISTICA 6.1.478.0. 


\section{Results and discussion}

The first step in solving the problem of finding physiological peculiarities in transformation of an operator's reliability was developing means for its simulation. When designing a computer model on occupational activity it is necessary to provide for certain events, occurring in real conditions of the operator's performance, contradicting to the given algorithm of a human behavior. The nature of such events may be very different. For example, when simulating an occupational activity in conditions of the multicriteria media an operator should seek for a compromise, finding of which is always associated with a partial failure in keeping to contradictory conditions, dictated by some rules. The results of such search are not always those, which fully satisfy the operator, so a negative emotional reaction can be developed. Of course, when simulating an operator's activity it is almost impossible to get a similar effect, because providing for similar situations requires development of a super complicated and very specific computed program, which cannot be universal. Such situation cannot satisfy an investigator. Therefore, in order to generate conflicting situations, causing negative emotional reactions in operators, one should search for other approaches.

As an emotional stimulus it is possible to use a variety of effects on humans; there are dozens of them. But, each effect should be significant for the operator. Among popular and well-proven methods for emotion stimulation in modeling such procedures are: increasing the sense of responsibility, when performing a task (by reward or punishment); organization of competitive conditions (computer games); unexpected effects different by their manifestations and direction (sound, light); unpleasant actions (pictures affecting psychics, movies, etc.); artificial complications when performing the assigned tasks (barriers similar to activities by the content, presenting an unfilled task during competitions, and so on); creating difficulties (such as deficiency of time and information, coordinative complexity for a performing a task; inattention in conditions of an acute interest to the task, etc.); monotony (performing a very simple task), and others.

The basis of the proposed approach in simulating the operator's activity for psychophysiological assessment of the reliability of the information processing was an information model for generation of contradic- tory constellations, based on the physiological effect of a clash by I. P. Pavlov. Among a number of such effects, being one of the most attractive in simulation, one can choose a method of disorientation, taken by means of the false information about successful performance of the proposed computed tasks. An important element of the proposed simulation is a «generator of false errors».

The realization of the information load was made by using a so-called Stroop interference effect. Stroop Test is a reliable tool for studying characteristics of attention and short-term memory [2, 7]. In performance of the Stroop task it is necessary to match colors of the «visual form» for a word and meaning of the word itself, ignoring the color of letters. The interaction of factors «color» and «meaning of the word» occurs due to performance of the task through empirical uncertainty in conditions of implementation of two possible ways of recognizing the color, directed at function of the first and the second signal systems of the human body. The mentioned interaction occurs on the background of the interference with the effect of mutual depression of a number of concurrent processes - perception of the color of graphic frames, semantics of the word and ignoring the color of the word, which occur in conditions of uncertainty in the sequence of implementing these phenomena. The task of ignoring color words complicates the interference pattern, because there appears an additional operation inhibition [1].

When the operator's actions corresponded to the given algorithm behavior, the next task was proposed. Under wrong operator's actions a short light and sound warning appears, informing about a mistake. In addition to the given probability a message was generated about a mistake, when the operator's action was correct. So, using a generator of fictitious errors, a procedure of occurring a clash effect was realized, accompanied by a spike of the operator's negative emotions. Reaching changes in the emotional state of the studied individuals was a predictable result of the effect of testing with the use of the generator of fictitious errors.

The next stage of the study was to analyze the transformation of the emotional state of the subjects after working with the test. The averaged data of the indices in the scales of subjective ratings of mental actual states are presented in Table 1 .

Analysis of these data makes it possible to conclude, that intensive information loading in simula- 
Indicators of subjective ratings of mental actual states, scores

\begin{tabular}{|c|c|c|c|c|c|c|}
\hline \multirow{2}{*}{ Scales } & \multicolumn{3}{|c|}{ Before testing } & \multicolumn{3}{|c|}{ After testing } \\
\hline & $\mathbf{M} \pm \mathbf{m}$ & As & Ex & $\mathbf{M} \pm \mathbf{m}$ & As & Ex \\
\hline $\bar{P}$ & $13,25 \pm 0,49$ & $-0,37 \pm 0,31$ & $0,30 \pm 0,62$ & $11,33 \pm 0,57^{* * *}$ & $-0,42 \pm 0,31$ & $-0,25 \pm 0,62$ \\
\hline $\mathrm{E}$ & $13,78 \pm 0,48$ & $-0,30 \pm 0,31$ & $-0,45 \pm 0,62$ & $11,61 \pm 0,57^{* * *}$ & $-0,57 \pm 0,31$ & $-0,10 \pm 0,62$ \\
\hline A & $8,65 \pm 0,42$ & $0,63 \pm 0,31^{\circ}$ & $0,42 \pm 0,62$ & $7,60 \pm 0,46^{* *}$ & $-0,29 \pm 0,31$ & $-0,54 \pm 0,62$ \\
\hline $\mathrm{O}$ & $3,69 \pm 0,41$ & $0,89 \pm 0,31^{\mathrm{oo}}$ & $0,04 \pm 0,62$ & $3,39 \pm 0,47$ & $1,81 \pm 0,31^{\mathrm{ooo}}$ & $4,54 \pm 0,62^{\mathrm{ooo}}$ \\
\hline $\mathrm{N}$ & $3,64 \pm 0,41$ & $1,00 \pm 0,31^{\mathrm{oo}}$ & $0,13 \pm 0,62$ & $3,32 \pm 0,46^{*}$ & $1,82 \pm 0,31^{\mathrm{ooo}}$ & $4,61 \pm 0,62^{\text {ooo }}$ \\
\hline $\mathrm{V}$ & $3,01 \pm 0,37$ & $1,17 \pm 0,31^{\text {ooo }}$ & $0,84 \pm 0,62$ & $2,35 \pm 0,43^{* *}$ & $1,72 \pm 0,31^{\mathrm{ooo}}$ & $2,51 \pm 0,62^{\mathrm{ooo}}$ \\
\hline $\mathrm{D}$ & $2,84 \pm 0,40$ & $1,22 \pm 0,31^{\text {ooo }}$ & $0,93 \pm 0,62$ & $2,97 \pm 0,51$ & $1,86 \pm 0,31^{\text {ooo }}$ & $3,31 \pm 0,62^{\text {ooo }}$ \\
\hline $\mathrm{S}$ & $2,19 \pm 0,35$ & $1,52 \pm 0,31^{\text {ooo }}$ & $2,71 \pm 0,62^{\text {ooo }}$ & $2,25 \pm 0,43$ & $1,77 \pm 0,31^{\text {ooo }}$ & $2,79 \pm 0,62^{\text {ooo }}$ \\
\hline
\end{tabular}

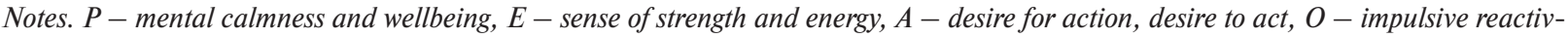
ity, $N$ - sense of mental anxiety or anger and tension, $V$ - feeling of anxious expectation, fear, anxiety, $D-p s y c h i c$ depression and feeling of exhaustion), $S$-depressed mood, stress; *, **, *** significant difference between groups correspond to $-p<0,05, p<0,01$, $p<0,001$ levels, respectively by the Wilcoxon criterion; ${ }^{o},{ }^{o o}$, ooo significant availability of asymmetry and excess by Student $t$-test criteria, correspond to $p<0,05, p<0,01, p<0,001$ levels.

tion of contradictory constellations affects significantly the emotional background of the examined individuals, by the most of its characteristics.

In all cases, the expressiveness of individual components after loading is decreased. That is, we can state the availability of changes in the emotional state of the examined subjects as a result of using an information load. But such change was not at all of a one-way direction. After testing, the level of the indicator of mental calmness and wellbeing was significantly decreased. The feeling of strength and energy was decreased as well as the desire for action. And such feelings as mental anxiety or indignation and strain as well as worried expectation, fear, concern and fearfulness have been also significantly decreased. However, unlike the first three groups of feelings (P, E, A), such feelings as (N, $\mathrm{V})$ showed a much lower level before testing and, so, their decrease probably did not give a marked contribution to changes in the emotional state of the tested.

At the same time by indices of asymmetry and excess in the examined samples it is seen that the analyzed data are not of a normal distribution, because according to the majority of indices there is an expressed asymmetry and excess, both before and after the intensive information load. So, the studied group is not homogeneous and a histogram of each indicator shows some peaks. Therefore, in order to get more uniform results, the examined group, using a cluster analysis (k-means), was divided into two subgroups. The scale indices of the subjective ratings of mental actual states, received in the subgroups, are presented in Table 2.
As it is seen from this Table, the level of certain components in the emotional stress in members of the subgroups is quite different. In the subgroup 2 the background value of the emotional strain is significantly low, than in the subgroup 1 by the majority of indices ( $\mathrm{A}, \mathrm{O}, \mathrm{N}, \mathrm{V}, \mathrm{D}, \mathrm{S})$. After the testing load the same indices are also significantly lower in the subgroup 2. However, by $\mathrm{P}$ and $\mathrm{E}$ indices such difference between subgroups was not observed. This indicates that despite the same expressiveness of mental calmness and wellbeing and feelings of strength and energy in these subgroups there is a significant difference in feelings of the desire for action, impulsive reactivity, mental anxiety, anxious expectation, fear, anxiety and in the depressed mood and stress.

The described situation indicates that members of the subgroup 2 , as a rule, are in the better emotional status; they are more positively tuned to performing a test task than representatives of the subgroup 1 .

The analysis of the impact of the information load allowed to somewhat specify the emotional transformation processes, occurring in representatives of both groups. The subgroup 1 is characterized by the impact of the testing load on decreasing the emotional strain by indices of mental calmness and wellbeing, however reducing feelings of strength and energy, intentions to actions, desire for action (P, E, A). In the subgroup 2 the same picture is observed, but feelings of anxious expectation, fear, anxiety and fear are added (V).

Thus, the distinguished subgroups differ significantly both by the background indices in the components of 
Characteristics of subgroups with different level of subjective assessments of mental actual states, score, $M \pm \mathrm{m}$

\begin{tabular}{|c|c|c|c|c|}
\hline \multirow{2}{*}{ Scales } & \multicolumn{2}{|c|}{ Subgroup 1 $(\mathbf{n}=\mathbf{1 4})$} & \multicolumn{2}{c|}{ Subgroup 2 $(\mathbf{n}=\mathbf{4 0})$} \\
\cline { 2 - 5 } & Before testing & After testing & Before testing & After testing \\
\hline P & $13,8 \pm 0,9$ & $11,7 \pm 0,9^{* *}$ & $13,1 \pm 0,6$ & $11,2 \pm 0,7^{\wedge \wedge \wedge}$ \\
\hline E & $14,5 \pm 0,9$ & $11,6 \pm 1,1^{* * *}$ & $13,6 \pm 0,6$ & $11,6 \pm 0,7^{\wedge \wedge \wedge}$ \\
\hline A & $11,3 \pm 1,0$ & $9,4 \pm 0,9^{* *}$ & $7,8 \pm 0,4^{\# \#}$ & $7,0 \pm 0,5^{\wedge \circ}$ \\
\hline O & $7,8 \pm 0,7$ & $7,6 \pm 1,2$ & $2,4 \pm 0,3^{\# \#}$ & $2,1 \pm 0,3^{\circ \circ \circ}$ \\
\hline N & $8,3 \pm 0,6$ & $7,8 \pm 1,0$ & $2,2 \pm 0,2^{\# \# \#}$ & $1,9 \pm 0,3^{\circ \circ \circ}$ \\
\hline V & $6,8 \pm 0,6$ & $7,0 \pm 0,9$ & $1,8 \pm 0,3^{\# \# \#}$ & $0,9 \pm 0,2^{\wedge \wedge \wedge \circ}$ \\
\hline D & $7,0 \pm 0,7$ & $8,4 \pm 1,1$ & $1,5 \pm 0,2^{\# \# \#}$ & $1,3 \pm 0,2^{\circ \circ \circ}$ \\
\hline S & $5,7 \pm 0,7$ & $7,0 \pm 0,9$ & $1,1 \pm 0,2^{\# \#}$ & $0,8 \pm 0,2^{\circ \circ \circ}$ \\
\hline
\end{tabular}

Notes. Marking scales are the same as in Table $1 .{ }^{*},{ }^{* *},{ }^{* * *}$ Significant difference of means between indices in the subgroups 1 before and after the information load by the Wilcoxon criterion corresponds to $p<0,05, p<0,01, p<0,001$ levels; ${ }^{\wedge},{ }^{\wedge}$ significant difference $^{\circ}$ of means between indices in the subgroup 2 before and after the information load by the Wilcoxon criterion corresponds to $p<0,05, p<$ 0,001 levels; ${ }^{\# \#}$ significant difference of means between indices of the subgroups 1 and 2 before the information load by the Wilcoxon criterion corresponds to $p<0,001$ level; ${ }^{o},{ }^{\text {oo }},{ }^{\text {ooo }}$ significance difference of means between indices of subgroups 1 and 2 after the information load by the Wilcoxon criterion corresponds to $p<0,05, p<0,01, p<0,001$ levels.

the emotional strain and by their characteristics after the information overload. Taking into account the list of psychological characteristics, which are significantly different as well as the substantial difference in levels, we can state that subjects of the subgroup 1 were in the «high» emotional strain, whereas representatives of the subgroup $2-$ in «moderate».

In the study of the operator's reliability the following moments have been taken into account: average response time, general probability of errors and probability of errors when giving a signal about a fictitious error. The statistical characteristics of indices on the reliability of the information processing by operators are shown in Table. 3. As it is seen from this Table, there is no significant difference between the average values of the parameters discussed in different periods of the study (I and II) for each of the subgroups ( 1 and 2), confirming the reliability of the proposed test.

At the same time, the analysis of the above table makes it possible to detect some interesting peculiarities. First, the average time for performing tasks in the subgroup 1 is essentially higher than in the subgroup 2. This indicates that individuals with «high» emotional strain perform their tasks more

Characteristics of the reliability of the information processing in individuals with different level of the emotional stress, $M \pm \mathrm{m}$

\begin{tabular}{|c|c|c|c|}
\hline Indices & Period of testing & Subgroup 1 & Subgroup 2 \\
\hline \multirow{2}{*}{$\begin{array}{l}\text { Average time } \\
\text { for solving a task, ms }\end{array}$} & $\mathrm{I}$ & $677 \pm 82^{* * *}$ & $507 \pm 66$ \\
\hline & II & $704 \pm 86^{* * *}$ & $526 \pm 67$ \\
\hline \multirow{2}{*}{ p, cu. } & I & $0,076 \pm 0,010^{* * *}$ & $0,045 \pm 0,004$ \\
\hline & II & $0,079 \pm 0,012^{* *}$ & $0,046 \pm 0,005$ \\
\hline \multirow[b]{2}{*}{$\mathrm{p}_{\mathrm{f}}, \mathrm{cu}$} & I & 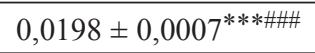 & $0,009 \pm 0,0004^{\# \# \#}$ \\
\hline & II & 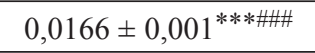 & $0,009 \pm 0,0005^{\# \# \#}$ \\
\hline \multirow{2}{*}{$\mathrm{p}_{\mathrm{h}}, \mathrm{cu}$} & I & $0,26 \pm 0,07^{* * *}$ & $0,02 \pm 0,01$ \\
\hline & II & $0,21 \pm 0,05^{* * *}$ & $0,02 \pm 0,01$ \\
\hline
\end{tabular}

Notes. $p_{f}$ - the probability of errors after submitting a signal on a wrong answer, $p_{h}-$ a part of errors after giving a signal on a wrong response among all false reactions; ** and *** - significant difference in mean values of the studied subgroups 1 and 2 by the $t$-Student's criteria corresponds to $p<0,01$ and $p<0,001$ levels; \#\#\# significant difference in the probability of errors during the analyzed period of testing $(p)$ and immediately after giving a signal on a wrong answer $\left(p_{f}\right)$, respectively, in each of the surveyed subgroups 1 or 2 in the first and second periods of testing by the t-Student's criteria corresponds to $p<0,001$ level. 
slowly than those with «moderate» strain. Second, in patients with «high» emotional strain the probability of errors is significantly higher, than in those with «moderate» emotional strain. Third, in individuals with «high» emotional strain the significantly higher probability of errors after the fictitious signal is recorded, than in those with «moderate» strain. Fourth, in patients with «high» emotional strain the probability of a negative reaction on a fictitious error is much higher (2,2 and 1,8 times, respectively at the first and second stages of the study), as compared to similar indices in individuals with «moderate» strain. In this, a part of such type of errors, on the average, is 11,8 times, $p<0,001$ higher in representatives of the subgroup 1, indicating a substantial difference in responses to a fictitious error in persons with various emotional strain.

In order to understand the obtained regularities it is necessary to make some comments. As numerous studies show, impulse signals have a certain effect on humans, being of a non-linear character. For example, by increasing the duration of the visual abovethreshold stimuli up to $30-150 \mathrm{~ms}$, a somewhat unexpected phenomenon can be observed - a nonlinear growth and then decrease in the feeling of brightness. As a result, a shorter light flash seems to be subjectively more significant, than longer flashes of the same brightness. This phenomenon of exceeding the brightness feeling is usually defined as a BrocaSulzer phenomenon, which is described in detail in the review by R. M. Meschersky[17]. This effect appears as a product of the generalized evaluation of brightness characteristics of the whole combination of the presented stimuli. An important fact in the BrocaSulzer effect is that the later part of the light flash, when using longer stimuli, seems to have a breaking retroactive effect. In other words, it reduces the sensation of brightness, caused by the previously received light flux. The obtained results make it possible to better understand, how objective properties of the external world are transforming, in order to become subjective properties of its perception.

The thing is that the described nonlinear effect is observed not only when presenting light signals [18, $19]$, but it is of more universal character. It appears when receiving sound [20,21], tactile [22], contrast (of different origin) and other signals, being of a sensory nature.

The important for a modern man is the effect of significant messages, being of exclusively informa- tional nature. The most important in such messages, irrespective by what sensory channels they come, is their meaningful interpretation by a person. When this interpretation is essential for vital human needs, such message can be called information. Of course, a short light flash and a sharp sound, according to the nonlinear Broca-Sulzer effect within a certain range of the time presentation, will be perceived as brighter or louder, respectively. But its additional stimulation will be provided exactly by the information, which is embedded in a light or a sound signal. So, a non expected impulse information signal with a certain psychological effect can, probably, be perceived as more intensive than a physical signal, which does not carry any additional information. An example of such signals can be not only a mine explosion (having not only a sound effect, but carrying a message about impending of danger), but, also, a message about a friend's sudden death or about an unpleasant contradictory message, causing a significant emotional burst, and others. The essential in this case is not an action of a physical message carrier, but a psychological emotional effect, having a definite meaning and color.

In the created model of the operator's performance such effect occurs, when suddenly the result of actions of the subject is not justified, which is in the contrary to the rules of an individual's activity. An «Error detector», found in the human body by N. P. Bekhtereva [23], as a result of comparing the supposed and real results, informs an individual all the time about the quality of the undertaken actions. When this detector gives a signal about correct actions, but the computer informs about a mistake, a reaction in the organism is developing, called by I. P. Pavlov as a clash. As a result, due to the inconsistency of the information received, a negatively dyed emotion is formed quite quickly, which reflects a body's response to a short-term «information impulse».

Considering the information signals of different nature one can suggest that when receiving short intensive information signals, their effect on the human body is, also, non-linear and has regularities of a subjective perceptibility, similar to those as in manifestations of the Broca-Sulzer effect. In the performed study the clash effect is of a short-term, impulsive character, changing the emotional background, where the events develop in conditions of the operator's information performance. The repeated 
significant increase in the probability of errors' occurrence after receiving a fictitious signal about a mistake, which is manifested immediately after the generation of such signal in individuals with «high» emotional stress, can be a proof of the short-term significant increase of the clash effect. Indeed, because the second and the subsequent tasks after a signal about a fictitious error are mainly performed correctly. Therefore, an assumption on the extending the Broca-Sulzer effect on the impulse information load is justified.

In discussing this issue, it should be noted that short-term above-threshold signals of different nature, seems to have a certain effect on development of stress reactions. Indeed, in war conditions there appears a lot of short-term high-power signals of different nature: physical (shooting with heavy weapons: reactive artillery, tanks, rocket launchers) and information (fear to have a wound, death or wounds of comrades, and so on.). These short-term emergency stimuli can influence not only directly but, also, indirectly, through manifestation of nonlinearity changes in impressions about combat factors, greatly enhancing the result of the direct effect of the environmental factors. As a result of the effect not only the reliability of performance can be decreased, but, also, a significant harm to the health of the military personnel can be made in reducing their combat capability.

In the experiments it is clearly seen that not only human physiological qualities affect the reliability of the operator's performance, but, also, parameters of the coming messages and interpretation of their content. In particular, the availability of more long-term responses to incoming messages in individuals with «high» emotional strain indicates less efficient function of their «error detector» in comparison with the sub-group with «middle» emotional strain. The availability of the negative aftereffect on the fictitious error in the first group was 13,0-10,5 times higher than in individuals with «middle» emotional strain. And, in general, the availability of a fictitious error makes individuals with «high» emotional strain to doubt on the correctness of their behavioral reactions. This is clearly seen in developing inverse of their reactions, manifested after a fictitious error.

Summing up we can say that individuals with «high» emotional strain, when assessing the reliability of the operator's performance in modeling an additional emotional load, have significantly worse indices in information processing by characteristics of the latency reaction periods and probability of errors, particularly those, related to signal on a fictitious incorrect response. This makes it possible to develop a discriminant model for evaluating the reliability of the operator's performance in modeling contradictory constellations $(p<0,001)$ :

$$
\begin{aligned}
& \mathrm{E} 1=-1,28+44,21 \cdot \mathrm{p}-4,25 \cdot \mathrm{p}_{\mathrm{h}} \\
& \mathrm{E} 2=-4,18+52,11 \cdot \mathrm{p}+7,21 \cdot \mathrm{p}_{\mathrm{h}},
\end{aligned}
$$

where the $p_{h}$ - a part of errors after a signal about a fictitious response among all false reactions, $\mathrm{p}-$ overall probability of errors.

Provided E1 > E2 an operator belongs to the group with high reliability of the operator' activity and with «moderate» emotional strain, in other case - to a «risk» group.

From the literature data it is known that the decrease in the emotional tone, as a result of a low need or completeness of the information in a subject (monotonous, stereotyped actions), leads to the loss of attention, skipping important signals, delayed reactions. On the other side, very high levels of the emotional strain disorganize the performance, complicates its tendency to premature reactions, reactions on external, insignificant signals (fictitious alarms), to primitive actions by the type of a blind search in a trial and error method.

Most of the works, where the effect of emotions on the cognitive functions has been studied, are associated with anxiety. The main result found in such works is in that anxiety leads to narrowing a field of attention. People, being in the state of anxiety, are concentrated on what they are afraid of, or on what can be important for their well-being; the other information is largely ignored [ 1,13$]$. Investigation of W. Waganaar [15] showed that events with vivid emotional colors are better hold in memory and are stand apart in the subject's living.

This study showed a clear negative effect of high emotional strain on the reliability of the information processing. There have been proposed approaches to psychophysiological assessment of the reliability in the information processing by military operators in conditions of simulation of the presentation of contradictory constellations, which can help to make a prognosis on the probability of appearing human errors under information overload conditions. 


\section{Conclusion}

1. It is found that the state of high emotional strain in military operators differs significantly both by the background indices of the components of the emotional strain and by their characteristics after an intensive information load, accompanied by maintenance of the imbalance in subjective assessments of mental states and after the information overload.

2. It has been formulated a hypothesis about the availability of non-linear effects, similar to the BrocaSulzer phenomenon, when processing the information messages, which significantly affect the reliability of the operator' performance. One of methods, contributing to manifestation of such effects, is inclusion of return signals on a fictitious signal error in the performance.

3. A method of psychophysiological assessment of the reliability of the operator's activity for military

\section{References}

1. Agafonov, A.Yu., Fedotova, A.Yu. 2005, Studies on the Stroop phenomenon when complicating an ignoring task, Psychological studies. Collection of sci. works, Samara: Universe-group, pp. 28-35. (in Russian)

2. Dormashev, Yu. B., Romanov, V. Ya., Shilko, R. S. 2003, "Interaction of the attention and short-term memorizing: a new research method (presentation 1)", Psikhologicheskii zhurnal, v. 24, тo. 3, pp. 72-79 (in Russian).

3. Kalnish, V. V., Levchenko, V. V. 2012, "Computer modeling of emotional states", Medical information and engineering, no. 3, pp. 34-39 (in Russian).

4. Karpov, A. V. 1991, Psychology in adopting decisions in occupational activity. Yaroslav : Yaroslav State University, 153 p. (in Russian).

5. Kotik, M., Yemelyanov, A. M. 1993, Nature of errors in a man-operator. Moscow : Transport, 253 p. (in Russian).

6. Matyukhin, V. V. 1993, "Mental work capacity from the point of view of the theory on functional systems: review of literature", Meditsina truda i prom. ekologia, no. 3-4, pp. 28-31 (in Russian).

7. Romanov, V. Ya., Dormashev, Yu. B., Shilko, R. S. 2003, "Interaction of the attention and short-term memorizing: a new research method (presentation 2)", Psikhologicheskii zhurnal, v. 24, pp. 47-53 (in Russian).

8. Sopov, V. F. 2005, Mental states in tension occupational performance: a learning aid, Moscow: Akademicheskii proekt, 128 p. (in Russian).

9. Sudakov, K. V. 1992, Mechanisms of congestive changes in limbo-reticular brain structures under an operators, based on simulation of the presentation of contradictory constellations (a clash effect by I. P. Pavlov) has been developed, which additionally can generate certain negative emotional states during intensive information flows processing.

4. A significant difference has been revealed in responses to fictitious errors in individuals with different emotional strain, characterized by a significantly higher (by 11,8 times, $\mathrm{p}<0,001$, on the average) part of probability of occurrence of a false reaction after a fictitious signal about an erroneous action in individuals with high emotional strain.

5. A model on decision support for physicians in assessing the reliability of an operator's activity by psychophysiological characteristics has been developed and criteria for referring an operator to the group of individuals with high or low level of reliability in processing the contradictory information have been distinguished.

emotional stress, Psikhoemotsionalnyi stress (Ed. V. K. Sudakov), Moscow: Sci. Res. Institute of Normal Physiology named after P.K. Anokhin, v. 1, pp. 7-27 (in Russian).

10. Toffler, E. 2002, Shock of the future: translation from English. Moscow : AST Publication, 557 p. (in Russian).

11. Ulybin, S. V. 2008, «Psychological factors affecting human occupational performance», Mir psikhologii, no. 4, pp. 262-268 (in Russian).

12. Broadbent, D. E., Broadbent, M. 1988, "Anxiety and attention bias: State and trait", Cognition and emotion, v. 2, pp. 165-183.

13. Mathews, A. 1993, "Biases in emotional processing", The Psychologists: Bulletin of the British Psychological Society, v. 6, pp. 493-499.

14. Maynard, D. C., Hakel, M. D. 1997, "Effects of objective and subjective task complexity on performance", Human Performance, v. 10, no. 4, pp. 303-330.

15. Waganaar, W. A. 1986, "My memory: A study of autobiographic memory over six years", Cognitive psychology, v. 18, pp. 225-252.

16. Wilson, T. D. 2001, "Information overload: implications for healthcare services", Health Informatics Journal, no. 7, pp. 112-117.

17. Meschersky, P. M. 1985, A Broca-Sulzer effect. Moscow : Nauka, 144 p. (in Russian).

18. Greene, E. 2013, "Violation of Bloch's Law that specifies reciprocity of intensity and duration with brief light flashes", Perception, v. 8, no. 4, pp. 543-550.

19. Gorea, A., Tyler, C. W., 2013, «Dips and bumps: on Bloch's law and the Broca-Sulzer phenomenon", Proc. Nat. Acad. Sci.USA, v. 110, no. 15, p. 1330. 
20. Springer Handbook of Speech Processing 2007, (Eds. J. Benesty, M. M. Sondhi. Y. Huang: Springer Science \& Business Media, 1176 p.

21. Olaf Strelcyk, Nazarin Nooraei, Sridhar Kalluri, Brent Edwards. 2012, "Restoration of loudness summation and differential loudness growth in hearingimpaired listeners", J. Acoust. Soc. Am., v. 132, no. 4, pp. 2557-2568.
22. Kim, S. S., Gomez-Ramires, M., Thakur, P. H., Hsiao, S. S. 2015, "Multimodal interactions between proprioceptive and cutaneous signals in primary somatosensory cortex", Neuron, v. 86, no. 2, pp. 555-566.

23. Bekhtereva, N. P. 1971, Neurophysiological aspects of human mental performance. Leningrad : Meditsina, 119 p. (in Russian).

\section{Кальниш В.', Швешь А. ${ }^{2}$ ЗАКОНОМІРНОСТІ ЗМІНИ НААІЙНОСТІ АІЯАЬНОСТІ ВІЙСЬКОВИХ ОПЕРАТОРІВ}

'Аержавна установа «Інститут меАишини праші Нашіональної академії меАичних наук України», М. Київ

Військова медична академія України, м. Київ

Bcmyn. Явище надмірного інформаційного перевантаження певним чином віддзеркалюється на надійності та працездатності військовослужбовців, стимулює підвищення їхнього емоційного негативно забарвленого напруження. Об`єктивне існування надмірного психоемоційного навантаження в сучасної людини вимагає розробки нового, більш досконалого погляду на оцінку надійності ії праці, а також створення нових психофізіологічних підходів для обгрунтування модерної технології психофізіологічної оцінки надійності операторської діяльності (НОД) в умовах дефіциту інформації та часу.

Мета дослідження - виявити закономірності та аналіз психофізіологічного особливостей зміни надійності діяльності військовослужбовців, що виконують роботу з переробки суперечливої інформації в умовах дефіциту часу. Матеріали та методи дослідження. Дослідження НОД при моделюванні потоку завдань з суперечливою інформацією проводилося в 2012-2013 роках. Вибірка досліджуваних осіб складалася з 54 військовослужбовців чоловічої статі віком 22-25 років, які перебували в стані гострого емоційного напруження, обумовленого процедурою вступу у вищий військовий навчальний заклад. Для дослідження емоційного статусу використовували шкалу суб'єктивних оцінок психічних станів СОПАС-8. Було застосовано спеціально сконструйовану комп ютерну програму, яка дозволяла моделювати операторську діяльність з переробки інформації в умовах дефіциту часу, яка з заданою імовірністю супроводжувалася констеляцією певних суперечливих подій, що входили в протиріччя з заданим алгоритмом дій оператора, «М.O.Е.».

Результати. Інтенсивне інформаційне навантаження при моделюванні суперечливих констеляцій суттєво впливає на емоційний фон обстежених осіб за більшістю показників його характеристик. Виділено дві групи операторів, які мали суттєво різні рівні емоційного напруження, та характеризувались неоднаковими показниками НОД (достовірно більша, у середньому в 11,8 разу, р < 0,001, імовірність виникнення помилкової реакції після фіктивного сигналу про помилкову дію в осіб з високим емоційним напруженням. Розроблено розв'язувальні правила, які дозволяють класифікувати операторів на групи з високим або низьким рівнем надійності обробки суперечливої інформації.

Висновки. Виявлено, що в стані високого емоційного напруження військовослужбовці суттєво розрізняються як за фоновими показниками компонентів емоційного напруження, так і за його характеристиками після інтенсивного інформаційного навантаження, що супроводжується збереженням розбалансованості суб'єктивних оцінок психічних станів і після інформаційного навантаження. Сформульовано гіпотезу щодо наявності нелінійних ефектів, подібних до ефекту Брока-Зульцера, при переробці імпульсних інформаційних повідомлень, які суттєво впливають на надійність операторської діяльності. Розроблено метод психофізіологічної оцінки надійності операторської діяльності військовослужбовців, який базується на моделюванні подання суперечливих констеляцій (ефект зштовхнення І. П. Павлова) та дозволяє додатково сформувати певні негативні емоційні стани при переробці інтенсивного потоку інформації. Виявлено суттєву різницю реакцій на фіктивну помилку в осіб з різним емоційним напруженням, яка характеризується достовірно більшою (у середньому в 11,8 разу, р < 0,001) долею імовірності виникнення помилкової реакції після фіктивного сигналу про помилкову дію в осіб з високим емоційним напруженням. Розроблено модель підтримки прийняття рішення лікаря при оцінюванні надійності операторської діяльності за психофізіологічними характеристиками та критерії віднесення досліджуваного оператора до групи з високим або низьким рівнем надійності обробки суперечливої інформації.

Ключові слова: надійність діяльності, емоційний стан, модельована суперечлива інформація, ефект Брока-Зульцера 


\section{Кальниш В.', Швец А. ${ }^{2}$}

\section{ЗАКОНОМЕРНОСТИ ИВМЕНЕНИЯ НААЕХКНОСТИ АЕЯТЕАЬНОСТИ ВОЕННЫХ ОПЕРАТОРОВ ПРИ ПОАУЧЕНИИ МОАЕАЬНОЙ ПРОТИВОРЕЧИВОЙ ИНФОРМАЧИИ}

'Государственное учрежление «Институт медицины труда Национальной акалемии медишинских наук Украины», г. Киев

\section{Военная медицинская акамемия Украины, г. Киев}

Введение. Явление чрезмерной информационной перегрузки определенным образом отражается на надежности и работоспособности военнослужащих, стимулирует повышение их негативно окрашенного эмоционального напряжения. Объективное существование чрезмерной психоэмоциональной нагрузки у современного человека требует разработки нового, более совершенного взгляда на оценку надежности его работы, а также создание новых психофизиологических подходов для обоснования современной технологии психофизиологической оценки надежности операторской деятельности (НОД) в условиях дефицита информации и времени.

Цель исследования - выявление закономерностей и анализ психофизиологических особенностей изменения надежности деятельности военнослужащих, выполняющих работу по переработке противоречивой информации в условиях дефицита времени.

Материалы и методы исследования. Исследование НОД при моделировании потока задач с противоречивой информацией проводилось в течение 2012-2013 годов. Выборка испытуемых состояла из 54 военнослужащих мужского пола в возрасте 22-25 лет, которые находились в состоянии острого эмоционального напряжения, обусловленного процедурой вступления в высшее военное учебное заведение. Для исследования эмоционального статуса использовалась шкала субъективных оценок психических состояний СОПАС-8. Была использована специально сконструированная компьютерная программа, которая позволяла моделировать операторскую деятельность по переработке информации в условиях дефицита времени, при которой с заданной вероятностью предъявлялись констелляции определенных противоречивых событий, не согласованных с заданным алгоритмом действий оператора «M.O.E.».

Результаты. Интенсивная информационная нагрузка при моделировании противоречивых констелляций существенно влияет на эмоциональный фон обследованных лиц по большинству показателей его характеристик. Выделены две группы операторов, которые имели существенно разные уровни эмоционального напряжения, и характеризовались неодинаковыми показателями НОД (достоверно больше, в среднем в 11,8 раза, р < 0,001, вероятность возникновения неправильной реакции после фиктивного сигнала об ошибочном действии у лиц с высоким эмоциональным напряжением. Разработаны решающие правила, которые позволяют классифицировать операторов на группы с высоким или низким уровнем надежности обработки противоречивой информации.

Bыводы. Выявлено, что в состоянии высокого эмоционального напряжения военнослужащие существенно различаются как по фоновым показателям компонентов эмоционального напряжения, так и по его характеристикам после интенсивной информационной нагрузки, сопровождающегося сохранением разбалансированности субъективных оценок психических состояний после информационной нагрузки. Сформулирована гипотеза о наличии нелинейных эффектов, подобных эффекту Брока-Зульцера, при переработке импульсных информационных сообщений, которые существенно влияют на надежность операторской деятельности. Разработан метод психофизиологической оценки надежности операторской деятельности военнослужащих, который основан на моделировании предъявления противоречивых констелляций (эффект сшибки И. П. Павлова) и позволяет дополнительно сформировать определенные негативные эмоциональные состояния при переработке интенсивного потока информации. Выявлено существенное различие реакций на фиктивную ошибку у лиц с разным эмоциональным напряжением, которое характеризуется достоверно большей (в среднем в 11,8 раза, p < 0,001) долей вероятности возникновения ложной реакции после фиктивного сигнала об ошибочном действии у лиц с высоким эмоциональным напряжением. Разработана модель поддержки принятия решения врача при оценке надежности операторской деятельности по психофизиологическим характеристикам и критерии отнесения исследуемого оператора к группе с высоким или низким уровнем надежности обработки противоречивой информации.

Ключевые слова: надежность деятельности, эмоциональное состояние, моделируемая противоречивая информация, эффект Брока-Зульцера

Надійшла: 8 червня 2016 р.

Контактна особа: Кальниш В. В., ДУ «Інститут медицини праці НАМН України», буд. 75, вул. Саксаганського, м. Київ, 01033. Тел.: +38 0442843427. 